\title{
TRAINING INITIATIVES FOR SKILLS ACQUISITION IN ICTS BY ACADEMIC STAFF OF THE UNIVERSITY OF CALABAR, CALABAR, NIGERIA
}

RUTH SIMON BASSEY AND ERIC T. OFRE

(Received 21, February 2013; Revision Accepted 22, March 2013)

\begin{abstract}
This study sought to assess training initiatives for skills acquisition in ICTs by academic staff of the University of Calabar. A descriptive survey design and the random sampling procedure were used to administer 150 copies of a validated questionnaire to academic staff of the university. Of these, 90 usable copies representing a $60 \%$ response rate were returned. Results showed that academic staff used ICTs for communication, teaching and learning activities, also that they acquired skills in ICTs through personal effort rather than formal staff development process. The study therefore concluded that academic staff may not be in a position to actively embrace innovative uses of ICT in teaching and learning because of little or no formal training and recommended that the University management should direct and ensure that a training program be designed and implemented to support academic staff in their understanding and application of ICTs in student learning. Also that, the staff development division should encourage and strengthen teaching staff professional development through subsidized training cost and improved sponsorship for workshops, seminars and conferences aimed at providing an understanding of available technologies and how these might be utilized in support of teaching, learning and assessment .
\end{abstract}

KEY WORDS: Information and Communication Technologies, Skills Acquisition, University Education, Academic Staff, Professional Development.

\section{INTRODUCTION}

Knowledge based activities have become increasingly important and pervasive worldwide. (Khalil et al, 2009). While information and communication technologies (ICTS) is said to be the foundation and driving force of this development, f̂tertiary education is deemed to be central to the creation of the intellectual capacity on which knowledge production and utilization depend and to the promotion of lifelong learning practices necessary to update individual knowledge and skillsò(Ojedokun, 2007). Against these dynamics, tertiary education must provide effective leadership in ICT integration through research and modeling as well as provide opportunities for professional development to boost quality service delivery in both academic and non academic aspects of its operations.
However, there seems to be a growing pressure on tertiary education in Africa as a whole to increase efficiency and relevance as well as improve the quality of its products. In real terms, these challenges translate to: producing graduates with relevant skills to function in the age of globalization; producing graduates who can create and adapt knowledge to new situation; and establishing linkages as well as partnerships with other knowledge producing organizations for knowledge enhancement and further discoveries (Ojedokun, 2007). Without doubt, the use of ICTs has been identified as the major activity that should be addressed if Nigeria must make progress in her educational system. Against the backdrop of the poor quality of graduates churned out from Nigerian universities, arising from poor infrastructural facilities for teaching and learning, proliferation of programmes and

Ruth Simon Bassey, University Librarian, University of Calabar, Nigeria

Eric T. Ofre, University Librarian, University of Calabar, Nigeria 
inadequate manpower among others, ñthe National Universities Commission (NUC) is fashioning out modalities for the establishing of a

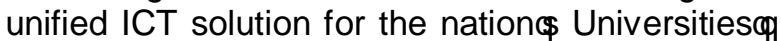
(Okojie, 2010). The component of the proposed ICT solution would include broadband connectivity, alternative energy solutions, capacity building in ICTs and a host of online services at the network management centre.

Arguably, technological innovations are transforming the educational landscape with vision and expertise for building open educational resources for participatory learning systems. Odegbami (2005) defines the emerging concept of the ớrtualô university as meaning that the university can offer its services via data networks, its training and researches also being established on information highways. The trend towards electronic and interactive distance learning is contingent upon increasing number of students, reducing and limited resources, and greater dispersed centres of need as well as availability of new delivery technological systems irrespective of place, time and device used. Arising from this scenario, is the question as to whether there exist required levels of ICTs skills among university staff to take full advantage of technology and meet demands?

\section{Statement of the Problem}

The effective integration of ICTs into the process of teaching, learning, research, information management and dissemination in Nigerian universities is fraught with challenges which must be addressed to ensure affordable and sustainable access. So daunting have the challenges been that the current assessment of ICTs having more impact on administrative processes such as admission, registration, fee payment and purchasing than on the fundamentals of classroom teaching and learning cannot be downplayed (Gambari and ChikeOkoli, 2007). If anything, such impact is seen to be changing the learning experience of students by relaxing time and space constraints as well as providing easier access to information, online journals, e-books and student portals, etc. The fact however, remains that ICT revolution in learning has transformed available technologies as regards methods of learning/studying. When integrated into education, computer and internet technologies can improve teaching and learning, strengthen teacher professional development, support broad educational reforms, enhance school community partnerships, and improve school management (Ekpenyong, 2005). To make this possible, however an enabling environment is necessary to support university computerization programme and internet connectivity.
The challenges posed by ICTs for human resource development in the university sector have necessitated this bid to provide a current perspective on issues involved in ICT skills acquisition of academic staff in the University of Calabar. Specially, the study aimed to achieve the following objectives.

i) Determine academic staff experience and competence in using ICTs in specific areas of academic work.

ii) Assess the mode of training in skills acquisition with respect to technique, duration, contents and teaching methods.

iii) Ascertain what academic staff perceive to be constraints to skills acquisition and;

iv) Verify academic staff opinions on perceived usefulness of training to academic work.

\section{Literature Review}

The widespread use of ICTs in the provision of quality education and research in tertiary institutions is being advocated globally. Arguably, the electronic work environment in universities makes new, innovative formats for teaching and learning activities possible, to which professional competence needs to be applied (Graves, 2001). As new technologies increasingly transform classroom interactions, University teachers need to be aware of, and understand the innovative potential of the technology that is available for their research and teaching, and also develop specific, appropriate and new competencies to cope with technological challenges in the work place.

Given the above, universities are faced with the demand that they play their part both in providing opportunities for lifelong learning and in revolutionizing the ways in which they deliver education. (Clegg, Konrad and Tan, 2000). Accordingly, the integration of Nigerian universities into the global knowledge system, so as to secure affordable access to ICTs and ensure its effective integration into the process of teaching/learning and information management has been highlighted in the literature. Gambari and Chike-Okoli (2007), Eke (2006), Ibrahim (2005), and many others have identified challenges of high cost of connectivity, shortages of skilled staff/limited expertise and overall lack of infrastructure, which should be addressed to stimulate development and interconnection of national education and research networks and achieve collaborative approaches. Ibrahim (2005) elaborated on the human capacity deficit challenge, citing it among the basic reasons why there is yet to be a truly functional national network backbone in Nigeria. He identified more than a dozen different project efforts to create National Research and Education Networks 
(NRENS) in Nigeria since 1992 and explained that many of the projects placed too much emphasis on the financial components, on buildings and equipment; and too little on capacity building and social engineering aspects of networking. Significantly, that where training was envisioned, it was mainly for technicians with little thought for user education and professional development.

Whereas ICTs have not yet revolutionized classroom interactions in Nigerian universities for obvious reasons, it is reported that elsewhere many institutions of higher learning are already advanced users of ICTs, using cutting-edge technologies such as interactive white boards, posting curriculum and home work on the internet and making use of video conferencing to share specialist teaching (Russel, 2000). Other information products said to be prevalent in the classroom of the future have been mentioned by Preston cited in Ojedokun and Owolabi (2003) to include: electronic white boards, which enable a teacher to write on the board in a conventional way while interacting with the computer at the same time, delivery of lesson notes in the form of interactive presentations which are projected onto the whiteboard incorporating video, animation and sound, and liquid crystal display (LCD) projectors which are used in a similar way to project video images on live television. Correspondingly, Lacey (1999) mentions the new set of skills that scholars must develop to include, strategies to search for relevant materials, skills in evaluating the quality of documents found, knowledge of web designs, skills in using discussion forums and chatrooms, and a basic understanding of how to send e-mail attachment.

In a related dimension, Harle (2009) examines the role that academic librarians can play in helping to develop the skills of their students and academic colleagues to handle information, which is critical to improving the overall quality of studentsôlearning and vital in preparing them for employment beyond university. He explains that academic librarians and their libraries are critical to the future development of high quality higher education institutions as new tools and technology revolutionize how student and scholars access information; and that libraries and librarians must be recognized as critical strategic partners, bringing their traditional expertise and skills, adding new professional capacities, and working closely alongside senior managers and other departmental colleagues to develop new tools and facilities for research, teaching and learning. In particular, that librarians involvement in monitoring and assessing the use of online materials could offer teaching staff valuable tools to aid student assessment and help to maintain quality in the learning process.

Although the consideration of information literacy component of university staff ICT development is beyond the scope of current research, Raseroka cited in Harle (2008) noted that universities which find a way to integrate information literacy in their teaching and learning, equipping graduates to be flexible and resourceful workers, may add considerable value to their degree programmes. At this juncture, it becomes important finding out the level of Nigerian universities librariansôpreparedness to fulfill the aforementioned role. An insight provided by Ajidahun (2007) on training, development and education of library manpower in 21 Nigerian University libraries showed that many academic librarians were not computer literate, and training programmes for staff development in ICTs were grossly inadequate.

At the same time, researchers exploring ICTs availability, access and use by university staff have provided more analytical perspective on the challenge that ICTs presents for human resource development of academics whose formative educational experiences and professional orientation were shaped under different circumstances. The consensus regarding Nigeria and many other developing economies has been that training programmes for staff development in ICTs are grossly inadequate and that it is imperative that universities enable and encourage the development of staff membersôcompetencies if they should act strategically in the field of ICT driven innovation.

Ojedokun and Owolabi (2003) for instance, who studied internet access, competence and the use of internet for teaching and research activities by University of Botswana academic staff, reported that many of the respondents were skilled users of the internet only as far as its application in research activities was concerned. That the respondents seemed not to be skilled in the use of the internet to enhance teaching activities, such as delivering additional lecture notes and sending files to students would emphasis the imperative that adequate training facilities be provided to enable staff members become well grounded in the use of ICTs for enhanced teaching performance. For the respondents of Ajala, Adegun, Adetunji and Oyewumi (2010) also, e-mail and web browsing were considerably used for research, while discussion groups, file transfer and telnet which pertain to classroom interactions were rarely used. Nwokedi (2007) reported similar findings for the academic staff of faculty of medical 
sciences, University of Jos, Nigeria, and recommended that university authority should place more emphasis on the use of the internet for teaching and also organize workshops for staff members on the use of the internet for teaching and also research. In his study, Eke (2006) identified lack of expertise/training among the factors impeding ICTs awareness and use by academic staff of tertiary institutions in Imo state, Nigeria. Accordingly academics were urged to make self conscious efforts aimed at acquiring requisite practical and operational knowledge of the computer and other ICT facilities.

The above scenario notwithstanding, it is noted that some other studies, reporting higher frequencies of ICTs use for teaching and corresponding competency levels in the use of ICT facilities, may be giving credence to Clegg, Konrad, and Tan $\hat{\Phi}$ (2000) observation that: while an innovative and enthusiastic minority are already actively researching and implementing open and distance learning (ODL) using ICTs, there is a larger cautious skeptical majority yet to become involved. For instance, Akinjide and Oyeboade (2007) investigated academic staff utilization of ICTs in selected Nigerian universities and showed higher frequencies of ICTs use for teaching and learning (64.9\%), than research activities (51.1\%). The authors equally reported corresponding competency levels in the use of ICT facilities by respondents for cellular phones, printers, electronic photocopiers, computers, internet connection/e-mail, fax and scanning machines respectively. It was however discovered that the acquisition of competence and skills in ICT use was attributed to personal efforts and investment. In the same vein, Ani, Edem and Ottong (2010) whose research aimed to investigate extent/level of internet access and use by academic staff in the University of Calabar, corroborated this problem of inadequacy of training programmes for staff development in ICTs in Nigerian universities. Their findings showed the basic reasons for internet access and use by the respondents as communication through e-mail, teaching, and research related activities respectively, and despite that there existed a high level of skills in internet access and use by the respondents, the authors recognized the need to organize regular user training by the university management for staff members in all Nigerian universities.

The challenges cited in the foregoing, arising from the pressure of academic staff to respond to changes produced by the increasing globalization of education markets, and the capacities of ICTs to transform the ways education is delivered should make for the consideration of the framework for effective delivery of staff ICT development. This research aims to generate data as well as explore issues involved in skills acquisition of University of Calabar academic staff for ICTs development.

\section{Methodology}

The study was carried out in the University of Calabar in Cross River State, Nigeria. Descriptive survey method was adopted for the study because of its value in accessing respondentsôopinions towards providing accurate description of the situation in focus at any given point in time.

The population of the study comprised of 1,150 subjects being the total population of academic staff from the faculties and institutes of the surveyed university. Of this population, a sampling frame of 150 subjects, representing approximately 13 percent of the total population was used for the study.

A structured questionnaire titled ñTraining Initiatives in Skills Acquisition for ICTsò was the main instrument for data collection. One hundred and fifty (150) copies of the questionnaire were randomly distributed to study subjects respectively at General Studies Examination and Academic Staff Union of Universities (ASUU) meetings which attract academic staff from all faculties and institutes of the university. The distribution was done by the researchers and follow-up visits were made by research assistants to retrieve outstanding copies. Of the total number of 150 copies of questionnaire distributed, 90 copies, representing 60 percent response rate were retrieved and used for analysis.

\section{RESULTS}

\section{Bio-data of Respondents}

The analysis of background information provided by respondents was done by gender, professional rank, work experience and faculty. These showed that there were more males (73\%) than female $(27 \%)$ participants. Also, majority $(46 \%)$ were of the rank of lecturers $1 / 11,32 \%$ were senior lecturers, whilst the remaining $22 \%$ were readers and professors. About $48.8 \%$ of the respondents had worked in the university for up to 10 years, $30.6 \%$, had $10-19$ years work experience, $13.6 \%$ had worked for $25-30$ years whereas the least category being that of above 30 years had only $3 \%$ respondents. The data further showed that $74.7 \%$ of the respondents were in non science-based disciplines while $25.3 \%$ were in science-based disciplines.

\section{Experience in ICTs Usage and Competence of the Respondents}

Results on experience of ICT usage and competence of respondents showed that majority 
(54.4\%) had used ICTs for $1-2$ years, followed by $31 \%$ who had used ICTs for 2-5years. The negligible $14.3 \%$ comprised of respondents who had used ICTs for less than a year (8.8\%) and $5.5 \%$ non-users.

The above notwithstanding, all respondents claimed some level of competence in ICTs usage for specific areas of academic work. Disaggregating the finding by individual items, it was indicated that competence in ICTs usage was mostly reflected in communication (68\%), teaching (62\%), research activities (61\%) and preparation/updating of lecture notes (57\%). There was also the indication that respondentsô were competent in deploying ICTs for other tasks like marking and recording of grades, community service, practical work, examination administration and statistical analysis though in a declining order of importance.

\section{Techniques for Skills Acquisition in ICTs} The data presented in Table 2 established the fact that all respondents had one form of training or the other on ICTs usage. While a significant majority (84\%) claimed that they acquired ICTs skills through self education, only $2.2 \%$ were trained through university sponsorship. Other training initiatives employed by respondents to a lesser extent included: coaching by friends and associates, attending private training centres and attending workshops and seminars mounted by professional associations.

Table 2: Training Initiatives for Skill Acquisition in ICTs

\begin{tabular}{|l|l|l|}
\hline Mode of Training & Frequency & $\%$ \\
\hline Self Education & 72 & 80 \\
\hline Coaching by friends and associates & 11 & 12 \\
\hline Attending private training centres & 3 & 3.3 \\
\hline $\begin{array}{l}\text { Attending workshops and seminars by } \\
\text { professional bodies. }\end{array}$ & 2 & 2.2 \\
\hline University sponsorship & 2 & 2.2 \\
\hline Total & $\mathbf{9 0}$ & $\mathbf{1 0 0}$ \\
\hline
\end{tabular}

\section{Duration of Training in ICTs for Skills acquisition}

The study findings on the duration of respondents training for skills acquisition revealed the most dominant training period to be six months (32\%), followed by 1 month (22\%), whilst the least was that of more than 6 months as represented by $13 \%$ respondents.

\section{Components of ICTs Training and Teaching Methods for Skills acquisition}

The data on Table 4 show the four major components of the training received by respondents to be word processing (97\%), basic systems operations/capabilities (92\%), internet browsing and networking (88\%) and ICT infrastructure and services (59\%). In contrast, other components like software application and development, IT consulting and systems maintenance featured to a lesser extent. It was however interesting to note that additional components like D-base and excel spreadsheet which were not listed in the options provided were also mentioned.

Table 4: Components of ICTs Training

\begin{tabular}{|l|l|l|}
\hline Components of Training Programmes & Frequency & $\%$ \\
\hline Word processing & 87 & $97 \%$ \\
\hline Basic systems operations/capabilities & 83 & $92 \%$ \\
\hline Internet browsing and networking & 79 & 88 \\
\hline $\begin{array}{l}\text { Infrastructure and services software } \\
\text { application and development }\end{array}$ & 37 & 41 \\
\hline IT consulting & 21 & 23 \\
\hline Systems maintenance & 15 & 17 \\
\hline
\end{tabular}

On finding out the teaching methods adopted by respondents for skills acquisition, two main methods of delivering training emerged and these were practical demonstrations (91\%) and formal lectures (86\%). In comparison, discussions and practical exercises were highlighted by $36 \%$ respondents respectively. 
Constraints to Skills Acquisition in ICTs

The data on factors which respondents perceived to be constraining skills acquisition in ICTs, captured all the options highlighted in their order of importance as: Epileptic Power Supply (74\%); insufficient IT facilities (74\%), training cost (63\%), time constraints (54\%); man-power inadequacy (52\%) and lack of awareness of IT potential to which one of the $31 \%$ respondents added r̃on the part of university managementò

\section{Perceived Usefulness of Acquired Skills on Respondents Academic Work}

On the above issue, it was observed that more than half of the respondents registered no comments. Of the remaining who were disposed to comment on their experience, two categories of opinions emerged. The first category featured brief general comments like óery useful, very necessaryô éxxeptionally usefulôand the like. In contrast, quite a number of respondents made comments which were considered significant to the study outcome and few of these are provided below;

? Training has opened my eyes to the potentials of using ICTs for research. It is simply amazing and fulfilling.

? It has improved my practical skills in the use of computer, especially in the area of power point presentation.

? It enables me to obtain updated information in my area of specialization and facilitates the preparation and presentation of results.

? Most useful, but paucity of relevant equipment and infrastructure tend to hinder continuity in ICT application by lecturers in the university.

? More staff should be exposed to training and sponsored to workshops and seminars.

? Enables me to keep track of change in course content, allows for confidentiality and forestalls exam leakages.

\section{DISCUSSION}

The results of this study reveal generally that the deployment of ICTs by academic staff is impacting profoundly on their tasks and skills in university education. The reasons may include an understanding of the benefits of ICTs as demonstrated by the respondents of Akinjide and Oyeboade (2007) who made regular use of ICTs facilities to communicate with their colleagues, to engage in research activities as well as for teaching and learning purposes.

In particular, the considerable level of competence existing among the respondents in using ICTs for specific areas of academic work was revealed and this seems to be consistent with the findings of some earlier studies (e.g. Ani, Edem, and Ottong, 2010) where a high level of skills in internet access and use for communication through e-mail, teaching and research related activities was reported by the respondents. For the respondents in other related studies (e.g. Ojedokun and Owolabi, 2003 and Ajala, Adegun, Adetunji and Oyewumi, 2010) however, internet use skills went only as far as its application in research activities were concerned, the respondents were not so skilled in the use of the internet to enhance teaching and learning activities. Arguably, academic research is presently augmented with the use of ICTs in order to extend access to research findings and keep academics abreast of current development in their respective disciplines and related interests. Apart from this, academic success and promotion in Nigerian Universities remain more closely tied to externally validated peer research than they do to teaching.

The study also found out that the acquisition of competence and skills for ICTs use among the respondents was more of personal effort than formal staff development processes like sponsorship for formal training, and relevant workshops/seminars which a negligible percentage reported. This finding however

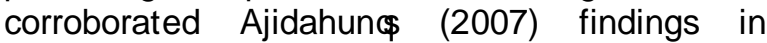
respect of academic librarians in Nigerian universities where of the 21 universities libraries surveyed, only 6 had staff who received computer training through formal education; one of these libraries depended on the use of workshops and seminars, whilst on-the-job training was the most popular method employed because university libraries could not afford to release their staff to go back to school either for part or full time studies on computer literacy. Ajidahun cited other constraints to formal staff development process to include; time and work commitment, limited infrastructure, cost implications and manpower constraints. Clegg, Konrad, and Tan (2000) provided further insight on the time and work commitment stating that, for many lecturers continued professional development in the core functions of teaching and learning competes with the pressures to become more active in research, with pressures of administration and a culture of busyness.

On the components that formed the core of respondents skills acquisition, this study revealed that respondents majored more on word processing, basic systems operation/capabilities and internet browsing and networking than in other areas. Asim, Ani and Kalu (2007) reported similar findings of more emphasis on general computing to the disadvantage of development of internet and programming skills. On comparing this with Mirrillâิ (2000) skills demand profile 
which shows that networking and internet skills top the list of highly sought after skills followed by programming, a change in focus was suggested to equip Nigerian youth or graduates with necessary ICT skills to compete in the global labour market. Furthermore, Clegg, Konrad and Tan (2000) explain that majority of academic staff have not been in a position to actively embrace innovative uses of ICTs in teaching and learning, because of little or no formal training, and added that acquired skills may include their basic use as a research tool for sourcing references and a word processor. In this view, ICTs skills lacking among academic staff could easily be identified, together with the demand for the high level of professional expertise required to plan and implement effective training programmes.

At this juncture, it becomes pertinent to mention that the ICTs component of the University of Calabar staff development programme is yet to be implemented. The current practice is for academic staff to take advantage of available training opportunities to build up knowledge and skill for increased proficiency in the area of ICTs. One such opportunity is provided by AfriHUB which is a private ICT firm contracted by the university to undertake Universal Mandatory Information Technology Training (UMITT) for all students as well as interested staff willing to sponsor themselves. The staff component of this initiative is called DITTO (Digital Train the Trainer Opportunity), which is a three week programme undertaken at staff convenience. It attracts a certificate of proficiency for successful completion and demonstrated competency in computer fundamentals, Microsoft (Word, Excel, Powerpoint and Access 2007) and internet utility and application.

Another finding of this study could also be relevant to those interested in effective delivery of academic staff ICT development. This showed that, epileptic power supply topped the respondentsô checklist of constraints to skills acquisition in ICTs, followed by insufficient IT facilities, training cost, time constraints, manpower inadequacy and lack of awareness of IT potentials. This finding, when combined with the possibility that universities might not also be disposed to planning and implementing adequate training programmes, pinpoints the likelihood that academic staff may continue to resort to ad-hoc training measures with a resultant effect of low level of skills development especially in the area of classroom interactions where efforts need to be directed and intensified.

\section{Recommendations and Conclusion}

The University of Calabar has a robust staff development policy, to enable staff acquire higher qualifications and requisite proficiency on their jobs. However, there are no formal training initiatives for staff to acquire ICT competence in classroom interactions. The researchers therefore recommend that the University should make adequate funds available for academic staff to attend ICT workshops and seminars by professional bodies to acquire competence specialised areas. The University authority must ensure that the ICT directorate initiates and designs more relevant training packages that will successfully address the needs of academic staff for teaching and learning activities. The University management should direct that applicants to academic positions demonstrate requisite competence in ICT for teaching and research before engagement.

Generally, this study has substantiated previous research findings that academic staff are more skilled in using ICTs for research purposes, than for teaching and learning activities because of little or no formal training. However, the need to integrate new technologies with the possibilities they imply for innovative teaching and learning demands conscious effort towards developing meaningful ICTs programme for academic staff by those responsible for staff development. The self conscious efforts made by staff to acquire requisite practical and operational skills in ICTs can be given a proper focus, if barriers and constraints to formal staff development processes are identified and resolved. These measures will improve access to ICTs and necessitate staff involvement that is both sustained and continuous if they are implemented.

\section{REFERENCES}

Ajala, I. O., Adegun, A. I., Adetunji, A. and Oyewumi, O. O., 2010. The Impact of internet use on teaching and research by Ladoke Akintola University of Technology (LAUTECH) academic staff. the information technologist 7(2): 187-198.

Ajidahun, C. O., 2007. The training, development and education of library manpower in information technology in university libraries in Nigeria. World Libraries 17(1): 1-13.

Akinjide, K. A. and Oyeboade, S. A., 2007. Academic staff utilization of information and telecommunication technologies (ICTs) in Nigeria tertiary institutions: a case study of ten selected universities. Gateway Library Journal 10(1) 33-42. 
Ani, O. E., Edem, M. B. and Ottong, E. J., 2010. Analysis of internet access and use by academic staff in University of Calabar, Calabar, Nigeria. Library Management 31(7): 535-545.

Asim, A. E., Ani, O. E. and Kalu, I., 2004. An assessment of information and communication technology (ICT) skills development: a case study of computer literacy centres in Cross River State, Nigeria. Nigerian Journal of Computer Literacy 5(1): 11-21.

Clegg, S., Konrad, J. and Tan, J., 2000. Preparing academic staff to use ICTs in support of student learning. International Journal of Academic Development. 5(2):138-148

Eke, F. M., 2006. Information and communication technologies (ICTs) awareness and use by academic staff of tertiary institutions in Imo State. Nigerian Library and Information Science Trend 4(172): 20-26.

Ekpenyong, G. D., 2007. Information and communication technology (ICT) assisted education. Paper presented in a symposium on issues, problems and prospects of modern IT in information professions. Department of LARIS, University of Ibadan.

Gambari, A. I. and Chike .O. A., 2007. Availability and Utilization of Information and Communication Technology (ICT) facilities inhigher institutions in Niger State, Nigeria. Thelnformation Technology Vol. 4 (1). 35-46.

Graves, W. H., 2001. Transforming traditional faculty roles, in technology-enhanced teaching and learning. Education Leadership Series 5, 35-44.

Harle, J., 2008. The information challenge for universities. Bulletin of the Association of Commonwealth Universities. 163: 14.
Harle, J., 2009. Dazzling technologies - the library place. Bulletin of the Association of Commonwealth Universities. 167: 30.

Ibrahim, A., 2005. Networking steps in Nigeria. AAU Newsletter II (3): 11-13.

Khahil, M., Dongier, P. and Qiang, C., 2009. Overview in: Information and Communications for Development. The World Bank: Washington, DC, 1-5.

Lacey, L., 1999. Using web-based distance education tools to promote health care research in developing countries. ALN Magazine 3(1): 1-8.

Nwokedi, V. C. , 2007. Impact of internet use on teaching and research activities of the academic staff of Faculty of Medical Sciences, University of Jos: a case study. Gateway Library Journal 10(1): 13-22.

Odegbami, O., 2002. A blueprint for implementing virtual libraries in Nigerian universities. Education Today: A Journal of the Federal Ministry of Education, 9(1): 17.

Ojedokun, A., 2007. Information literacy for tertiary education students in Africa. Ibadan: Third World Information Services Ltd.

Ojedokun, A. A. and Owalabi, E. O., 2003. Internet access, competence and the use of the internet for teaching and research activities by University of Botswana academic staff. African Journal of Library, Archives and Information Science 13(1): 43-53.

Okojie, J., 2010. NUC Plans Unified ICT Portal for Nigerian Universities. Daily Sun, 2 March, p 39

Russel, B., 2000. Learning online TWill Replace The Classroomòlndependent June 16, p11. 